\title{
Rola chemeryny i jej antybakteryjnych pochodnych w utrzymaniu funkcji barierowych nabłonka
}

\begin{abstract}
STRESZCZENIE
T

kanki nabłonkowe mają ciągły kontakt ze środowiskiem zewnętrznym, w tym z mikroorganizmami chorobotwórczymi. Wytwarzane przez komórki nabłonkowe endogenne białka i peptydy przeciwdrobnoustrojowe w sposób bezpośredni lub poprzez zaangażowanie do tego celu komórek odpornościowych kontrolują liczebność oraz skład populacji drobnoustrojów. Do tej grupy cząsteczek zaliczane są aktywne pochodne chemeryny, wielofunkcyjnego białka, wyposażonego zarówno w funkcję przeciwdrobnoustrojową, jak i chemotaktyczną. Ze względu na rosnącą liczbę infekcji wywoływanych przez mikroorganizmy niewrażliwe na antybiotyki, takie jak metycylinooporne szczepy gronkowca złocistego (MRSA), niezwykle ważne staje się zrozumienie mechanizmów kontroli drobnoustrojów zasiedlających miejsca barierowe, takie jak skóra i jama ustna. Syntetyczny peptyd 4 (p4), obejmujący centralną sekwencję $\mathrm{Val}^{66}-\mathrm{Pro}^{85}$ chemeryny, wykazuje szerokie spektrum aktywności przeciwdrobnoustrojowej przeciwko bakteriom skóry i jamy ustnej, łącznie z lekoopornymi szczepami MRSA. Cechy te czynią z niego peptyd o obiecującym potencjale terapeutycznym. $\mathrm{W}$ artykule prezentujemy przegląd ochronnych funkcji chemeryny oraz jej pochodnych $\mathbf{w}$ tkance nabłonkowej.
\end{abstract}

\section{BUDOWA I FUNKCJE CHEMERYNY}

Chemeryna jest małym ( 16 kDa), wszechobecnym białkiem o właściwościach regulujących zarówno odpowiedź immunologiczną, jak i procesy metaboliczne. Białko to zostało wykryte w 1997 roku, w obrębie skóry łuszczycowej leczonej za pomoca pochodnej kwasu retinowego - tazarotenu. W tak leczonych zmianach łuszczycowych zaobserwowano zwiększoną ekspresję genu RARRES2 (ang. retinoic acid receptor responder 2). $Z$ tego względu chemerynę nazwano początkowo białkiem TIG2 (ang. tazarotene-induced gene 2 protein) [1]. Pierwsze, funkcjonalne informacje o chemerynie pochodzą z 2003 roku, kiedy to została zidentyfikowana jako ligand dla sierocego receptora CMKLR1 (ang. chemokine-like receptor 1) [2].

Ludzka chemeryna syntetyzowana jest $\mathrm{w}$ formie nieaktywnej preprochemeryny, złożonej ze 163 aminokwasów, z których pierwsze 20 aminokwasów od strony N-końcowej stanowi peptyd sygnałowy. Po odcięciu peptydu sygnałowego, powstaje wydzielana do krwioobiegu, nieaktywna proforma chemeryny. Krążące we krwi białko wymaga dalszej, enzymatycznej modyfikacji końca karboksylowego, aby móc pełnić funkcje biologiczne [3] (Ryc. 1). W wyniku hydrolizy wiązań peptydowych od strony C-końca przez proteazy serynowe i cysteinowe, zaangażowane $\mathrm{w}$ procesy krzepnięcia, fibrynolizy oraz reakcje zapalne, powstają izoformy chemeryny o zróżnicowanej bioaktywności i właściwościach biologicznych (Ryc. 1). Niektóre z enzymów mogą przeprowadzać proteolizę końca karboksylowego białka w kilku różnych miejscach, a powstałe izoformy ulegać dalszej modyfikacji przez inne proteazy [4]. Cechująca się największą aktywnością chemotaktyczną chemeryna-157 (Chem157S) może powstać jako wynik bezpośredniego usunięcia 6 aminokwasów przez elastazę neutrofilową, katepsynę K lub L, bądź jako rezultat dwuetapowej modyfikacji proteolitycznej natywnego białka, w której uczestniczy w pierwszym etapie plazmina, a następnie karboksypeptydazy (B lub N). Z kolei pochodząca z komórek tucznych chymaza przekształca prochemerynę $w$ nieaktywną chemerynę-154 [5,6]. Oprócz czynników endogennych na aktywację chemeryny mogą wpływać enzymy wydzielane przez bakterie, których przykładem jest stafopaina B - proteaza cysteinowa stanowiąca potencjalny czynnik wirulencji Staphyloccocus aureus [7]. Pomimo braku danych krystalograficznych dotyczących struktury przestrzennej chemeryny, przewidywania dokonane na podstawie metody rozpoznawania zwojów (ang. fold recognition) pozwalają zaliczyć to białko do rodziny katelicydyn/cystatyn, należących do peptydów antybakteryjnych $[8,9]$.

\section{mgr Urszula Godlewska ${ }^{\square}$,}

mgr Aneta Zegar,

prof. dr hab. Joanna Cichy

Zakład Immunologii, Wydział Biochemii, Biofizyki i Biotechnologii, Uniwersytet Jagielloński, ul. Gronostajowa 7, 30-387 Kraków

https://doi.org/10.18388/pb.2020_323

๑autor korespondujący: urszula.godlewska@ doctoral.uj.edu.pl

Słowa kluczowe: chemeryna, peptydy przeciwdrobnoustrojowe, peptyd p4, ochrona przeciwbakteryjna, skóra, jama ustna

Wykaz stosowanych skrótów: AMP - peptydy przeciwdrobnoustrojowe (ang. antimicrobial peptides), CCRL2 - ang. chemokine (C-C motif) receptor-like 2, Chem157S - chemeryna 157S, CMKLR1 - ang. chemokine-like receptor 1, GPR1 - ang. G protein-coupled receptor 1, MIC - minimalne stężenie hamujące (ang. minimum inhibitory concentration), MRSA - metycylinooporny Staphylococcus aureus (ang. methicillin-resistant Staphylococcus aureus), RARRES2 - ang. retinoic acid receptor responder 2, TIG2 - ang. tazarotene-induced gene 2 protein

Podziękowania: Praca finansowana ze środków przyznanych przez Narodowe Centrum Nauki w ramach projektu UMO-2014/12/W/ NZ6/00454. Część grafiki prezentowanej na rycinach została zaadaptowana z ServierMedical Art (http:/ / smart.servier.com) i użyta na podstawie licencji Creative CommonsAttribution 3.0 Unported License (CC BY 3.0). 

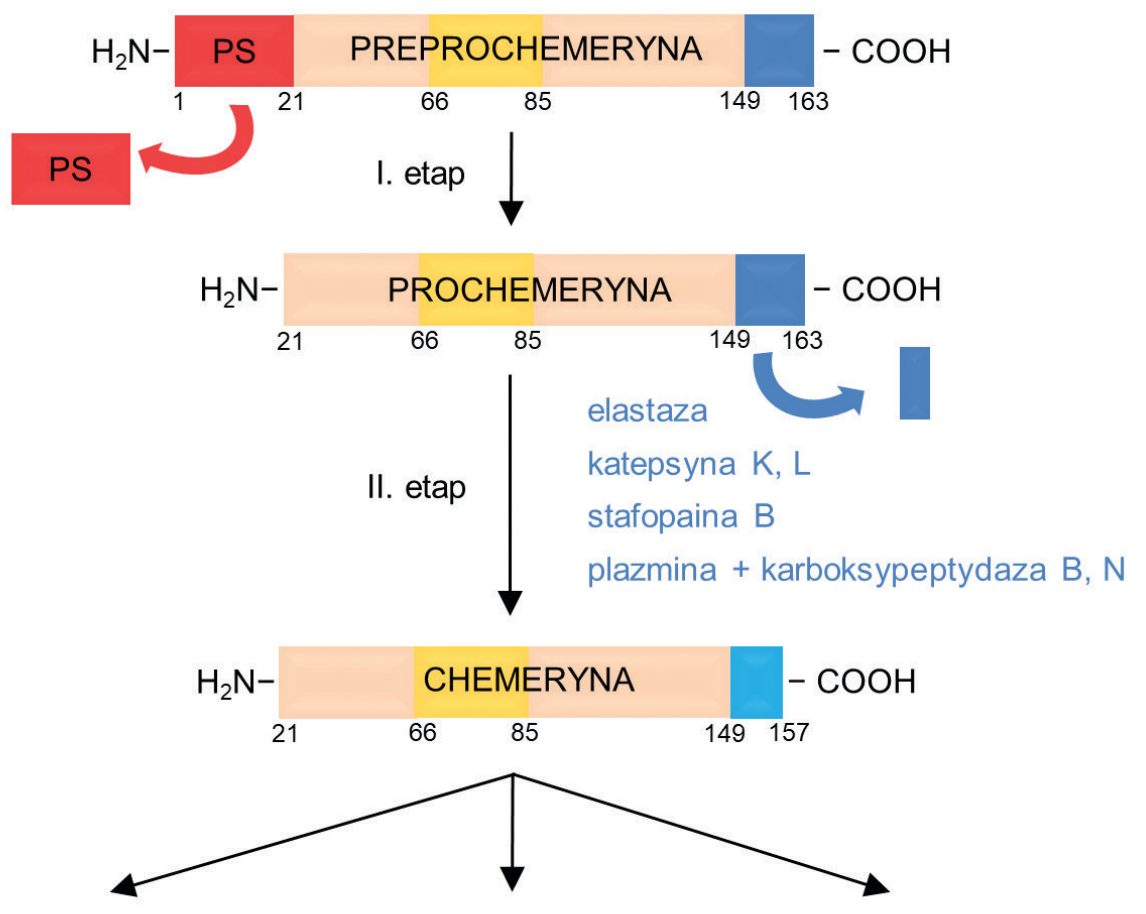

1

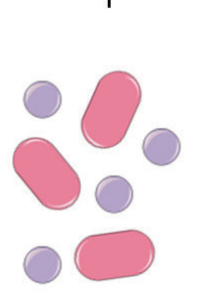

2

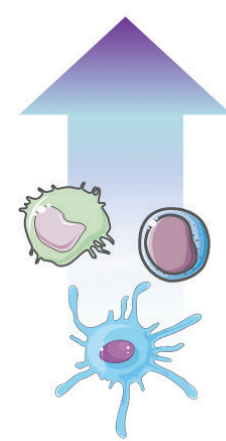

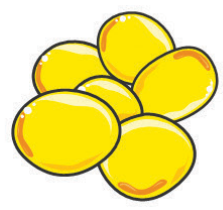

4

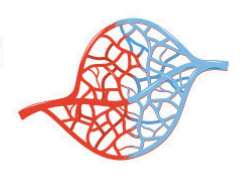

5

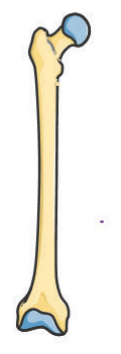

6

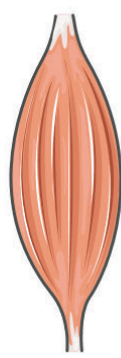

7

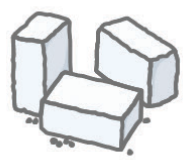

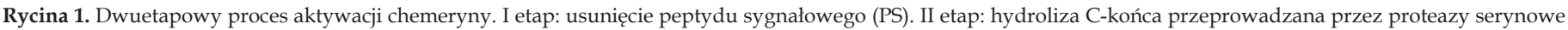

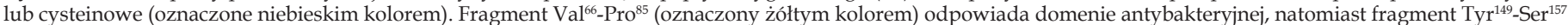

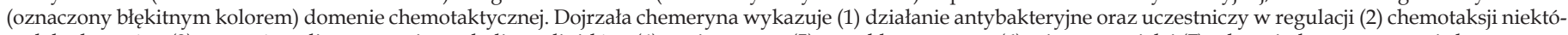

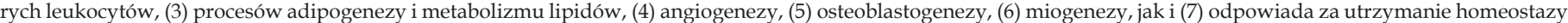
glukozy.

Obecnie znane są 3 transbłonowe receptory chemeryny, wszystkie sprzężone z białkami G (GPCR, ang. G Protein-Coupled Receptor). Pierwszy z nich, CMKLR1 jest syntetyzowany w różnych tkankach i narządach. Wysoka ekspresja mRNA dla tego receptora występuje w komórkach układu odpornościowego takich jak monocyty, makrofagi, komórki dendrytyczne i komórki NK oraz jest obserwowana m.in. w śledzionie, węzłach chłonnych, płucach, skórze i tkance tłuszczowej [10]. Peptyd Tyr ${ }^{149}-$ Ser $^{157}$ zlokalizowany na C-końcu chemeryny jest silnym agonistą dla receptora CMKLR1. Związanie chemeryny od strony końca karboksylowego do CMKLR1 indukuje internalizację kompleksu ligand-receptor, uwolnienie jonów wapnia do cytoplazmy oraz fosforylację kinaz MAP ERK1/2. Wysokim powinowactwem do chemeryny, ale wykazującym słabszą zdolność do przekazywania sygnału w porównaniu do
CMKLR1 charakteryzuje się receptor GPR1 (ang. G protein-coupled receptor 1) [11]. Chociaż jego występowanie jest związane głównie z ośrodkowym układem nerwowym, to mRNA kodujące GPR1 jest wykrywane m.in. w płucach, skórze i tkance tłuszczowej [10]. Z kolei atypowy receptor CCRL2 (ang. chemokine (C-C motif) receptor-like 2) pomimo porównywalnego do CMKLR1 i GPR1 poziomu wiązania chemeryny, nie indukuje wewnątrzkomórkowej ścieżki sygnałowej. Dlatego wydaje się, że jego funkcja polega na zwiększaniu lokalnego stężenia chemeryny i umożliwieniu interakcji chemeryny z CMKLR1 na sąsiadujących komórkach [11]. CCRL2 jest obecny na powierzchni leukocytów takich jak makrofagi, komórki dendrytyczne, neutrofile i limfocyty T [12].

Chemeryna jest szeroko rozpowszechniona w tkankach i narządach ludzkich. Najwyższy poziom jej ekspresji wy- 
kazują takie organy jak wątroba, trzustka i nadnercza, ale mRNA kodujące chemerynę jest wykrywane również $\mathrm{w}$ tkance tłuszczowej, skórze, płucach i przewodzie pokarmowym, co sugeruje zaangażowanie chemeryny w wiele procesów fizjologicznych [13]. W miejscach toczącego się zapalenia wydzielanych jest wiele białek zdolnych do aktywacji prochemeryny. W zależności od klasy proteaz, które przeważają w mikrośrodowisku uszkodzonej tkanki, generowane są różne fragmenty chemeryny, wykazujące działanie pro- lub przeciwzapalne. Jednymi z pierwszych komórek, które napływają do takich miejsc są neutrofile, uwalniające ze swoich ziarnistości enzymy (elastazę, katepsynę G) zdolne do tworzenia bioaktywnych form chemeryny. Ten mechanizm umożliwia rekrutację komórek prezentujących antygen (APC, ang. antygen-presenting cells) - plazmacytoidalnych komórek dendrytycznych (pDC) i makrofagów oraz innych leukocytów posiadających na swojej powierzchni receptor CMKLR1, stanowiąc łącznik między nieswoistą i swoistą odpowiedzią immunologiczną [14]. Ostatnie badania in vivo potwierdziły rolę aktywowanego przez chemerynę receptora CMKLR1 w stymulacji migracji i aktywności angiogennej komórek śródbłonka naczyń [15]. W zdrowej skórze chemeryna jest produkowana głównie przez keratynocyty naskórka. Badania wykazały, że chemeryna stanowi ważny element obrony antybakteryjnej skóry hamując wzrost mikroorganizmów. Ponadto niektóre bakterie, podobnie jak mediatory ostrej fazy, takie jak onkostatyna $\mathrm{M} \mathrm{i}$ IL-1 $\beta$, zwiększają ekspresję chemeryny i receptora CMKLR1 $\mathrm{w}$ keratynocytach, co pozwala na wynaczynienie i migracje populacji leukocytów mogących bezpośrednio eliminować patogeny [16,17].

Wspomniane powyżej funkcje chemotaktyczne i antybakteryjne chemeryny, nie wyczerpują wszystkich możliwości działania tego białka (Ryc. 1). Chemeryna jest ważnym czynnikiem regulacyjnym tkanki tłuszczowej, ze względu na swoje zaangażowanie w kontrolę adipogenezy oraz metabolizmu komórek białek tkanki tłuszczowej. Adipocyty charakteryzują się wysoką ekspresją zarówno chemeryny jak i receptora CMKLR1, których poziom zwiększa się wraz z dojrzewaniem komórek prekursorowych [18]. Działając autokrynnie chemeryna steruje procesem różnicowania komórek tłuszczowych oraz zwiększa pobieranie przez nie glukozy. Działając z kolei parakrynnie może pośredniczyć w rekrutowaniu do tkanki tłuszczowej komórek CMKLR1 ${ }^{+}$, których zwiększoną akumulację obserwuje się u osób z otyłością [3]. Oprócz wyżej wspomnianych funkcji chemeryna wpływa także na fizjologię wielu innych narządów i tkanek (Ryc. 1). Uczestniczy m.in. w osteoblastogenezie, miogenezie, umożliwia prawidłowe funkcjonowanie nerek oraz utrzymanie homeostazy glukozy. Jej podwyższony poziom w surowicy krwi jest związany ze stanami patologicznymi takimi jak nadciśnienie, cukrzyca typu 2 czy choroba Leśniowskiego-Crohna. Ponadto obecność chemeryny została wykryta w płynach wysiękowych chorych na raka jajnika i płynach maziowych pacjentów $\mathrm{z}$ zapaleniem stawów. Chemeryna jest także uważana za marker wczesnych faz rozwoju łuszczycy $[3,10,14]$. Z kolei, w niektórych typach nowotworów obserwuje się znaczne obniżenie stężenia tego chemoatraktanta [14].

\section{PEPTYDY CHEMERYNOWE JAKO PRZYKŁAD NOWYCH PEPTYDÓW PRZECIWDROBNOUSTROJOWYCH}

Peptydy przeciwdrobnoustrojowe (AMP, ang. antimicrobial peptides) stanowią jeden $\mathrm{z}$ najbardziej konserwatywnych i powszechnych sposobów walki gospodarza z mikroorganizmami. Główną funkcją tych cząsteczek jest bezpośrednia eliminacja lub ograniczanie liczebności mikroorganizmów. Niemniej jednak, niektóre AMP mogą wykazywać dodatkowe właściwości, typowe dla czynników modulujących aktywność układu odporności. Mogą być zaangażowane m.in. w chemotaksję i aktywację komórek układu immunologicznego $[9,19,20]$. Dla podkreślenia roli AMP w kształtowaniu odpowiedzi immunologicznej, peptydy te są również określane mianem peptydów odpornościowych (HDP, ang. host defense peptides) [21,22]. AMP posiadają charakterystyczne cechy biochemiczne. Znaczącą większość AMP stanowią krótkie (10-50 aminokwasów), amfipatyczne peptydy, obdarzone dodatnim ładunkiem. Zależnie od składu aminokwasowego AMP mogą przyjmować formę a-helisy, $\beta$-kartki lub być pozbawione specyficznej konformacji drugorzędowej $[19,20]$. Wspomniane we wcześniejszym rozdziale właściwości immunomodulacyjne oraz antybakteryjne chemeryny czynią ją potencjalnym kandydatem do miana nowego AMP. Jednak, by móc jednoznacznie określić, czy białko to spełnia kryteria charakterystyczne dla peptydów przeciwdrobnoustrojowych należy przyjrzeć się dokładnie jego budowie, funkcji oraz regulacji.

Celem zidentyfikowania specyficznych epitopów w cząsteczce chemeryny, odpowiedzialnych za jej właściwości antybakteryjne przebadanych zostało 14 krótkich peptydów, odpowiadających sekwencji aminokwasowej całego białka. Wspomniane peptydy zostały chemicznie zsyntetyzowane i poddane analizie bioinformatycznej, jak również in silico oraz doświadczalnie oceniono ich potencjał antybakteryjny. Wielkość peptydów dobrano tak, by wynosiła \pm 20 aminokwasów, co odpowiada średniej długości cząsteczki AMP. Kolejnym kryterium przy projektowaniu peptydów, było uzyskanie takich cząsteczek, by wykazywały różnice w ładunku, hydrofobowości oraz strukturze drugorzędowej. Na tej podstawie możliwe było określenie, które fragmenty chemeryny determinują jej aktywność antybakteryjną. Najbardziej aktywnym bakteriobójczo fragmentem chemeryny okazał się syntetyczny peptyd obejmujący sekwencję Val ${ }^{6-}$ -Pro ${ }^{85}$, zwany dalej peptydem p4. Peptyd p4, ze względu na swoją budowę oraz właściwości fizykochemiczne idealnie spełnia kryteria klasycznego peptydu przeciwdrobnoustrojowego. Charakteryzuje go wysoka zawartość dodatnio naładowanych reszt aminokwasowych, które nadają mu silny, dodatni ładunek oraz skłonność do przyjmowania konformacji $\beta$-kartki [16]. Dokładniejsza charakterystyka p4 wykazała, że aby peptyd ten osiągnął maksimum swoich możliwości antybakteryjnych, musi spełnić kilka warunków, zależnych od unikatowej budowy aminokwasowej łańcucha polipeptydowego. W celu weryfikacji, które właściwości cząsteczki najsilniej determinują aktywność bakteriobójczą peptydu p4, przetestowano szereg analogów tego peptydu. Jednym z nich był peptyd typu scramble (scr-p4), o identycznym składzie reszt aminokwasowych, których rozmieszczenie różni się znacząco względem peptydu p4. Peptyd scr-p4 nie wykazywał właściwości antybakteryj- 
nych, charakterystycznych dla peptydu p4. Pomimo identycznego ładunku wynoszącego +5 , oba peptydy różnią się znacząco amfipatycznością, określaną na podstawie różnic $\mathrm{w}$ momencie hydrofobowym. Jak widać, zmiana ułożenia poszczególnych reszt aminokwasowych o właściwościach hydrofilowych i hydrofobowych, w przypadku obu peptydów wpływa na ich funkcje antybakteryjne. Z kolei, zamiana wszystkich czterech lizyn na pozbawione ładunku reszty alaniny, całkowicie znosi efekt antybakteryjny p4. Jest to spowodowane obniżeniem ładunku $\mathrm{z}+5 \mathrm{do}+1$. Co ciekawe, w tym przypadku oba peptydy, tj. p4 i p4, w którym lizyny zostały zamienione na alaniny, posiadają podobny charakter amfipatyczny. Natomiast, jeśli w miejscu lizyn podstawi się aminokwasy o podobnych właściwościach fizykochemicznych, takie jak arginina, silny potencjał antybakteryjny zostaje zachowany. Taka modyfikacja, znana pod pojęciem konserwatywnej substytucji aminokwasów gwarantuje zachowanie identycznych parametrów fizykochemicznych cząsteczki. Na podstawie tych danych można stwierdzić, że oba parametry, silny ładunek dodatni wraz z wysoką amfipatycznością peptydu są konieczne do zapewnienia pełnej aktywności antybakteryjnej p4 [23].

Regulacja poziomu ekspresji oraz aktywności peptydów antybakteryjnych jest ważnym aspektem utrzymania homeostazy organizmu. Zależny od warunków, różny poziom syntezy AMP jest jednym z mechanizmów ochrony organizmu przed nadmierną aktywnością tych peptydów. Peptydy antybakteryjne można głównie znaleźć w miejscach narażonych na stałą ekspozycję mikrobiologiczną. W takim środowisku istnieje konieczność ciągłej kontroli liczebności populacji drobnoustrojów. Stąd też, miejsca takie jak skóra, jelita, błony śluzowe układu pokarmowego, czy też rozrodczego są bogate w specyficzne AMP [20]. Dla przykładu, w naskórku peptydy takie jak $\beta$-defensyna 1 (HBD-1) oraz RNaza7 cechuje relatywnie stały poziom ekspresji, przypuszczalnie zapewniając tym samym konstytutywną ochronę przed patogenami $[20,24]$. W momencie zaistnienia konieczności wzmocnienia bariery antybakteryjnej, np. na skutek zranienia lub infekcji, ekspresja innych peptydów może ulec zmianie. W skórze notuje się wówczas podniesienie poziomu ekspresji genów kodujących szereg białek i peptydów o działaniu antybakteryjnym, $\mathrm{w}$ tym katelicydyny oraz chemeryny [24].

Skuteczną metodą regulacji endogennych peptydów jest synteza nieaktywnych biologicznie prekursorów, które dopiero $\mathrm{w}$ wyniku proteolizy, przyjmują formę aktywną. Taki model regulacji jest dobrze opisany dla ludzkiej katelicydyny hCAP18/LL-37, gdzie aktywny biologicznie peptyd LL37 powstaje po usunięciu domeny katelinowej z nieaktywnego białka prekursorowego hCAP18 [19]. Jak wspomniano $\mathrm{w}$ poprzednim rozdziale, chemeryna prezentuje podobieństwo struktury trzeciorzędowej do katelicydyn [8]. Należy jednak pamiętać, że pewne analogie między tymi białkami nie kończą się na podobieństwie strukturalnym. Podobnie jak w modelu aktywacji peptydu LL-37, chemeryna by pełnić swoje funkcje biologicznie musi ulec obróbce proteolitycznej do krótszych, aktywnych izoform. Chemeryna określana jako Chem157S jest czynną chemotaktycznie formą białka, jak również posiada potencjał antybakteryjny. Z kolei jeszcze krótsza forma Chem125R charakteryzuje się bra- kiem właściwości chemotaktycznych względem receptora CMKLR1, natomiast wykazuje podobną do formy $157 \mathrm{~S}$ aktywność bakteriobójczą względem E. coli [6]. Mechanizmy aktywacji chemeryny $\mathrm{w}$ płynach ustrojowych wraz z identyfikacją różnorodnych, skróconych form białka są relatywnie dobrze opisane [8]. Natomiast na dzień dzisiejszy niewiele jest dostępnych informacji na temat enzymatycznego procesowania i dostępności bioaktywnych fragmentów chemeryny produkowanych lokalnie np. w skórze. Jednakże, zważywszy na dużą zawartość enzymów proteolitycznych $\mathrm{w}$ skórze, $\mathrm{w}$ tym tych pochodzenia bakteryjnego, istnieje duże prawdopodobieństwo, że również w tym środowisku chemeryna ulega proteolizie do peptydów o aktywności przeciwdrobnoustrojowej [24]. Wydaje się za tym przemawiać zależna od chemeryny, wysoka aktywność antybakteryjna supernatantów pozyskanych z hodowli surogatów ludzkiego naskórka, tzw. hodowli 3D keratynocytów [16].

Kolejna analogia między katelicydynami, a chemeryną dotyczy obecności wysoce konserwatywnych fragmentów białka. Katelicydyny są szeroko rozpowszechnioną wśród kręgowców rodziną białek o specyficznej budowie. Typowa katelicydyna zawiera N-terminalny peptyd sygnałowy, wysoce konserwatywny region katelinowy oraz najbardziej zmienny ewolucyjnie C-końcowy fragment cząsteczki, kodujący dojrzały peptyd antydrobnoustrojowy [25]. Gdy przyjrzymy się strukturze chemeryny, zaobserwujemy, że najsilniej konserwatywnie zachowany rejon białka przypada na fragment rozpoczynający się od niezmiennej reszty glicyny w pozycji 63 i obejmuje ponad 50 reszt aminokwasowych, aż do niezmiennej proliny $\mathrm{w}$ pozycji 118 . W obrębie tego fragmentu znajduje się wysoce konserwatywna sekwencja odpowiadająca peptydowi p4. Spośród 20 aminokwasów składających się na peptyd p4, 13 reszt aminokwasowych pozostaje niezmiennych, natomiast $\mathrm{w}$ przypadku jednej reszty obserwuje się konserwatywne podstawienie aminokwasów. Co istotne, ta wspomniana konserwatywność dotyczy wielu reszt aminokwasowych istotnych z punktu widzenia aktywności antybakteryjnej peptydu [23].

Podsumowując, chemeryna wraz z jej antybakteryjnym fragmentem $\mathrm{p} 4$ posiada cechy charakterystyczne dla klasycznych AMP. Białko to może być zaangażowane w obronę przed drobnoustrojami $w$ dwojaki sposób: poprzez aktywację ekspresji i zwiększenie ilości całkowitego białka, jak również poprzez proteolityczną aktywację cząsteczki i pojawienie się krótkich izoform białka o działaniu antybakteryjnym.

\section{MECHANIZM DZIAŁANIA CHEMERYNOWEGO PEPTYDU P4}

Uszkodzenie błony cytoplazmatycznej jest jednym z głównych mechanizmów eliminacji bakterii przez AMP. Kationowe peptydy oddziałują $\mathrm{z}$ ujemnie naładowanymi grupami lipidowymi, budującymi błony mikroorganizmów na drodze interakcji elektrostatycznych. Amfipatyczny charakter AMP zapewnia możliwość interakcji zarówno z hydrofilowymi składnikami fosfolipidów, jak również z hydrofobowym rejonem błony. Rezultatem takiej interakcji jest zwiększenie przepuszczalności błony, jej uszkodzenie i/lub wejście peptydu do wnętrza komórki, gdzie może 
zaburzać działanie funkcji wewnątrzkomórkowych $[9,20]$. Mechanizm uszkodzenia błony bakteryjnej zależy od budowy peptydu. W modelu klepek beczki (ang. barrel-stave model) amfipatyczne AMP o strukturze a-helisy tworzą kanały w poprzek błony. W kolejnym modelu tzw. porów toroidalnych (ang. toroidal pore model), na skutek agregacji i zaginania monowarstwy lipidowej tworzone są jeszcze większe pory w błonie bakterii. Model dywanowy (ang. carpet model) polega na wytworzeniu na powierzchni błony warstwy złożonej z cząsteczek peptydów, których hydrofilowe regiony oddziałują z ujemnie naładowanymi głowami fosfolipidów. Szczelne pokrycie membrany może prowadzić do destabilizacji dwuwarstwy lipidowej [26]. Podobnie jak w przypadku innych AMP, mechanizm bakteriobójczy peptydu p4 również w głównej mierze polega na uszkodzeniu błony bakterii. Ekspozycja bakterii na działanie p4 skutkuje wzrostem przepuszczalności błony, jak również jej uszkodzeniem, zależnym od stężenia peptydu [23]. Jak wiadomo, błony komórek eukariotycznych różnią się składem od ich bakteryjnych odpowiedników. Większa zawartość lipidów o słabszym ładunku ujemnym, takich jak sfingomielina, czy cholesterol sprawia, że membrany eukariontów są mniej wrażliwe na działanie kationowych AMP $[9,27]$. Ma to potwierdzenie $\mathrm{w}$ działaniu peptydu p4 na komórki eukariotyczne. Nie obserwuje się uszkodzenia błony erytrocytów, nawet po zastosowaniu wysokich dawek p4. Analogicznie, błona keratynocytów wydaje się być niewrażliwa na aktywność p4, niemniej jednak w przypadku zastosowania wysokich dawek p4 obserwuje się wzrost przepuszczalności. Pomimo zmian świadczących o pewnym zaburzeniu funkcji błony, keratynocyty nie zmieniają swojego metabolizmu mitochondrialnego w teście MTT, który jest jednym z wyznaczników przeżywalności komórek. Podobnie, nie obserwuje się zmian cytotoksycznych w mysich keratynocytach, po uprzednim naniesieniu peptydu p4 na skórę myszy [23]. Przedstawione informacje wskazują, że peptyd p4 jest relatywnie bezpieczny dla komórek gospodarza i może pełnić rolę czynnika przeciwdrobnoustrojowego w miejscach barierowych, takich jak skóra.

Aktywność przeciwdrobnoustrojowa peptydów antybakteryjnych może być modulowana poprzez potranslacyjną modyfikację łańcucha polipeptydowego. Przykładem takiej modyfikacji jest tworzenie mostków dwusiarczkowych między resztami cysteiny [28]. Defensyny mogą posłużyć jako ciekawy przykład tego, jak wiązania dwusiarczkowe decydują o właściwościach biologicznych AMP. Przyjęcie przez $\beta$-defensynę 3 (HBD-3) struktury trzeciorzędowej, zależnej od wiązań dwusiarczkowych jest konieczne do prawidłowego związania się peptydu z receptorem CCR6. Tak więc, by HBD-3 mogła pełnić funkcje chemotaktyczne, musi ulec odpowiedniemu sfałdowaniu. Dla kontrastu, aktywność antybakteryjna HBD-3 nie zależy od przyjętej struktury trzeciorzędowej, gdyż forma linearna peptydu jest tak samo aktywna, co jej połączony mostkami dwusiarczkowymi odpowiednik [29]. Odmiennych obserwacji dokonano w przypadku HBD-1, której forma linearna, pozbawiona wiązań między cysteinami ma większy potencjał bakteriobójczy [30]. Peptyd p4 posiada w swojej sekwencji tylko jedną resztę cysteiny, stąd też niemożliwe jest przyjęcie przez cząsteczkę struktury trzeciorzędowej, stabilizowanej wiązaniem dwusiarczkowym. Jednakże brak tego aminokwasu wpływa istotnie na właściwości przeciwbakteryjne peptydu. Zamiana cysteiny na alaninę znacząco zmniejsza aktywność bakteriobójczą p4 względem E. coli i S. aureus. Podobnie sytuacja wygląda, gdy zablokuje się możliwość tworzenia wiązania dwusiarczkowego poprzez nieodwracalną redukcję i alkilacje grup sulfhydrylowych. Modyfikacje te prowadzą do spadku aktywności peptydu, porównywalnej do tej obserwowanej w przypadku peptydu pozbawionego cysteiny. Okazuje się, że możliwość utworzenia wiązania dwusiarczkowego między dwoma cząsteczkami p4 warunkuje właściwości przeciwdrobnoustrojowe peptydu. Dimer p4 wykazuje dużo wyższą aktywność przeciwbakteryjną w porównaniu do formy monomerycznej peptydu [23].

Modyfikacja AMP w formie dimeryzacji stanowi skuteczną metodę zwiększania aktywności biologicznej, selektywności oraz stabilności peptydów. Dimeryzacja sprawia, że AMP chętniej i łatwiej agregują, jak i uzyskują możliwość przyjmowania bardziej zdefiniowanej struktury drugorzędowej. Te cechy, wraz z jednoczesnym, lokalnym wzrostem ładunku oraz hydrofobowości na powierzchni peptydu sprzyjają wiązaniu się dimerów do składników błony. Dzięki takim zmianom, potrzeba znacznie mniej peptydów, by osiągnać próg permeabilizacji błony bakteryjnej. Ma to szczególne znaczenie dla peptydów, które prezentują dywanowy model uszkodzenia błony. W tym przypadku, by doszło do zaburzenia ciągłości dwuwarstwy lipidowej konieczne jest osiągnięcie progu wysycenia błony peptydami, po przekroczeniu którego dochodzi do masywnych uszkodzeń błony [31]. Peptyd p4 posiada zdolność interakcji z błoną bakterii niezależnie od przyjętej formy dimer/ monomer. Obie formy monomeryczne, tj. forma zredukowana peptydu oraz ta, z zablokowaną możliwością tworzenia mostku dwusiarczkowego wiążą się do powierzchni bakterii. Jednakże, samo związanie w tym wypadku jest niewystarczające do wygenerowania uszkodzeń błony koniecznych do zabicia bakterii. Podobnie, peptyd scr-p4, który posiada zdolność dimeryzacji oraz kationowy ładunek, niezbędny do oddziaływania z błoną mikroorganizmów nie wykazuje silnej aktywności przeciwbakteryjnej. Ma to związek z odmiennym rozmieszczeniem reszt hydrofilowych i hydrofobowych w cząsteczce scr-p4 [23]. Na tej podstawie można stwierdzić, że zarówno dodatni ładunek, zdolność do tworzenia dimeru oraz właściwości amfipatyczne cząsteczki są czynnikami niezbędnymi do zapewnienia antybakteryjnego potencjału peptydowi $\mathrm{p} 4$.

Zniszczenie błony bakteryjnej jest obserwowane tylko w przypadku zastosowania wysokich stężeń peptydu p4 (powyżej wartości MIC, ang. minimum inhibitory concentration). W niższych, bakteriostatycznych stężeniach działanie peptydu ograniczające wzrost bakterii jest widoczne, jakkolwiek nie obserwuje się zmian świadczących o uszkodzeniu struktur powierzchniowych bakterii. Sugeruje to istnienie innych mechanizmów hamujących wzrost mikroorganizmów, niezależnych od uszkodzenia błony [23]. AMP mogą ingerować $\mathrm{w}$ różnorodne procesy enzymatyczne bakterii. Przykładem takiego zaburzenia jest hamowanie syntezy składników komórki (np. ściany komórkowej, DNA, RNA) [27]. Poszukiwania mechanizmu działania p4, który funkcjonuje w stężeniach bakteriostatycznych rzuciły nowe światło na właściwości peptydu. Mianowicie, peptyd p4 


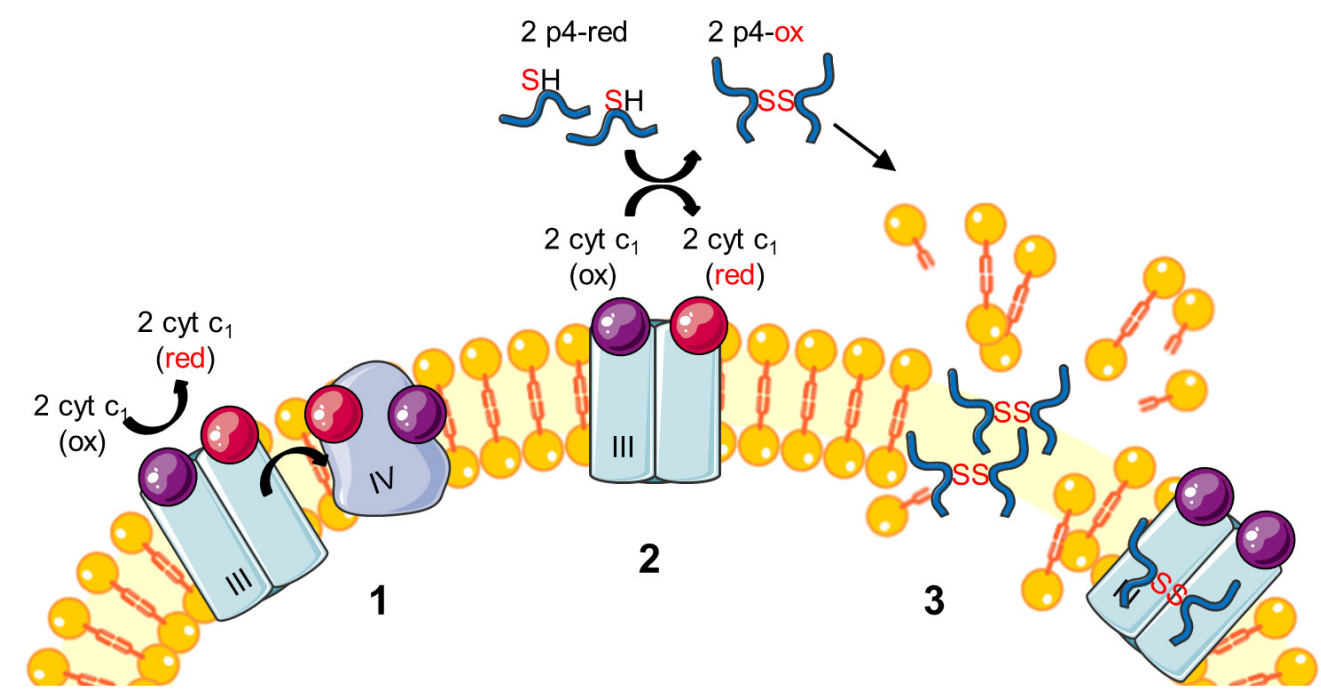

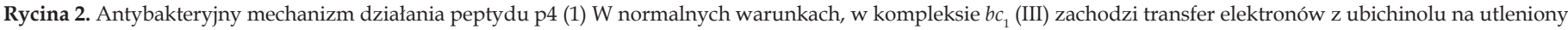

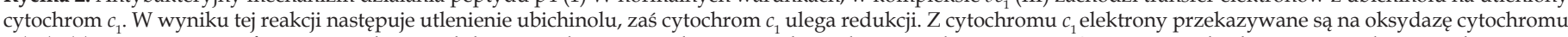

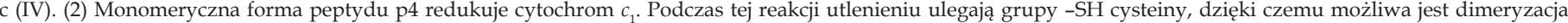
peptydu. (3). Dimer p4 uszkadza błonę bakterii oraz hamuje aktywność kompleksu $b c_{1}$.

może zaburzać czynność enzymatyczną bakteryjnego kompleksu cytochromu $b c_{1}$ który występuje u wielu, chodź nie $\mathrm{u}$ wszystkich bakterii [23]. Kompleks $b c_{1}$ jest bakteryjnym odpowiednikiem kompleksu III, zlokalizowanego w błonie mitochondrialnej. Odpowiada on za transfer elektronów $\mathrm{z}$ ubichinolu na cytochrom $c_{1}$ oraz generowanie gradientu protonowego. W wyniku tej reakcji ubichinol ulega utlenieniu, natomiast cytochrom $c_{1}$ redukcji [32]. Reakcja redukcji cytochromu $c_{1}$ może zostać indukowana $\mathrm{w}$ obecności monomerów p4 posiadających wolne grupy tiolowe. $\mathrm{W}$ następstwie tej reakcji tworzone są wiązania dwusiarczkowe między monomerami p4. Nowo powstałe dimery p4 mogą skuteczniej reagować z błoną bakteryjną. Co więcej, utleniona forma p4 pełni funkcje inhibitora kompleksu $b c_{1}$ [23]. Zatem mamy tu do czynienia $\mathrm{z}$ mechanizmem, w którym naturalnie występujące w komórce enzymy będą zwiększać aktywność peptydu antybakteryjnego (Ryc. 2).

\section{OCHRONNA ROLA CHEMERYNY W TKANCE NABEONKOWEJ}

Wielowarstwowy nabłonek skóry oraz błony śluzowej jamy ustnej tworzą wysoce wyspecjalizowane bariery, które chronią organizm przed uszkodzeniami fizycznymi i chemicznymi, inwazją patogenów, odwodnieniem, czy też utratą ciepła. W skórze funkcję pierwszej linii obrony przed infekcją zapewnia konstytutywne oraz indukowane wytwarzanie różnych AMP, w tym chemeryny. Właściwości ochronne bariery skórnej wykazują pewne różnice, w zależności od regionu skóry i istniejącego tam specyficznego mikrośrodowiska [24]. W zdrowej skórze chemeryna występuje $\mathrm{w}$ dużej ilości $\mathrm{w}$ naskórku, szczególnie $\mathrm{w}$ warstwie podstawnej [16]. Komórki leżące w tej warstwie odpowiadają za dostarczanie nowych keratynocytów do wyższych warstw epidermy. Niezróżnicowane komórki następnie przechodzą proces dojrzewania, aż $\mathrm{w}$ postaci $\mathrm{w}$ pełni zróżnicowanych korneocytów ulegają złuszczeniu. Mechanizm ten jest jedną z metod zapobiegania kolonizacji głębszych warstw skóry przez mikroorganizmy [24]. Obecność chemeryny w warstwie podstawnej może świadczyć o jej dodatkowej roli wzmacniającej antybakteryjne właściwości głębszych warstw naskórka. Potwierdzeniem dla tej tezy jest zwiększenie ilości chemeryny głównie w głębszych warstwach sztucznego modelu naskórka po ekspozycji na S. aureus [17]. Różne formy chemeryny oraz peptyd p4 wykazują aktywność przeciwbakteryjną względem S. aureus, w tym również metycylinoopornych szczepów (MRSA, ang. methicillin-resistant Staphylococcus aureus) $\mathrm{w}$ testach in vitro $[16,23]$. W modelu mysim zwierzęta pozbawione możliwości ekspresji chemeryny gorzej sobie radzą z ograniczeniem liczby S. aureus w porównaniu do myszy o dzikim fenotypie [17]. Analogicznie, gdy naskórek myszy dzikich zakazi się S. aureus można zaobserwować znaczące zahamowanie wzrostu bakterii $\mathrm{w}$ grupie myszy, którym naskórkowo podano peptyd p4 [23]. Poziom chemeryny zwiększa się w skórze podczas infekcji bakteryjnej S. aureus. Podniesieniu ulega również ekspresja wszystkich trzech receptorów wiążących chemerynę [17]. Pomimo tego, że rola receptorów CCRL2 oraz GPR1 w skórze wciąż pozostaje zagadką, istnieją pewne przesłanki ku temu, iż receptory te mogą uczestniczyć w lokalnej koncentracji chemeryny. Celem takiej miejscowej retencji chemeryny może być zwiększenie jej biodostępności dla komórek CMKLR1 ${ }^{+}$oraz możliwość bezpośredniej eliminacji patogenu [23]. Co ciekawe, chemeryna może zostać aktywowana przez enzymy proteolityczne pochodzenia bakteryjnego. Przykładem takiej proteazy jest produkowana przez S. aureus stafopaina B, procesująca nieaktywną formę białka do chemotaktycznej i antybakteryjnej formy Chem157S [8]. W przewlekłym stanie zapalnym, jaki ma miejsce $w$ chorobach takich jak łuszczyca, obserwuje się znaczący spadek chemeryny w naskórku [33]. Za obniżenie ekspresji chemeryny $\mathrm{w}$ epidermie odpowiadają charakterystyczne dla skóry łuszczycowej cytokiny IL-17 oraz IL-22 [17]. Spadek ilości chemeryny w epidermie jest skorelowany ze wzrostem S. aureus w skórze zmienionej chorobowo [34]. Podsumowując, wszystkie przedstawione dane, chemeryna 
i jej pochodne stanowią istotny czynnik ograniczający rozwój bakterii w skórze, a jej brak skutkuje wzrostem niepożądanych gatunków, takich jak $S$. aureus. To, w połączeniu ze zdolnościami chemotaktycznymi chemeryny czyni z niej istotny element wspierający funkcje bariery skórnej.

Mikrobiom jamy ustnej jest drugim po jelicie najbardziej złożonym ekosystemem bakteryjnym w ludzkim ciele. W jamie ustnej główną rolą AMP jest kontrola składu mikrobiomu. Peptydy przeciwdrobnoustrojowe stoją na straży ochrony błony śluzowej jamy ustnej przed nadmierną kolonizacją przez niepożądane mikroorganizmy [35,36]. Obecność chemeryny wykrywa się zarówno w warunkach homeostazy, jak i stanach zapalnych jamy ustnej. Chemeryna oraz peptyd p4 wykazują różnicowe właściwości antybakteryjne względem wybranych gatunków bakterii, zależnie od ich lokalizacji w biofilmie jamy ustnej oraz potencjału patogennego. Największą skuteczność peptydu p4 notuje się wobec paciorkowców, takich jak Streptococcus salivarius oraz Streptococcus sanguinis. Natomiast inne przebadane gatunki: Streptococcus oralis i Streptococcus gordonii są oporne na działanie p4 [37]. Wszystkie wymienione gatunki paciorkowców są uznawane za gatunki komensalne, które utrzymują mikrobiom jamy ustnej w stanie równowagi, ograniczając wzrost gatunków chorobotwórczych. Drugą ważną cechą charakteryzującą Streptococcus spp. jest ich rola w kształtowaniu biofilmu. Jako tzw. pierwotni kolonizatorzy, bakterie te jako pierwsze zasiedlają powierzchnię jamy ustnej umożliwiając agregację kolejnych gatunków i tworzenie dojrzałego biofilmu [38]. Drugim gatunkiem, niezmiernie ważnym z punktu widzenia tworzenia biofilmu jest Fusobacterium nucleatum. Bakterie te są zaangażowane w koordynacje agregacji wczesnych i późnych kolonizatorów, stanowiąc swoisty most dla gatunków patogennych, takich jak Porphyromonas gingivalis, czy Tannerella forsythia. Pomimo, iż peptyd p4 nie wykazuje zdolności bakteriobójczych względem $P$. gingivalis, czy T. forsythia, doskonale radzi sobie z ograniczaniem wzrostu różnych szczepów F. nucleatum. Dotyczy to również możliwości eradykacji $F$. nucleatum rosnących w biofilmie [37]. Przytoczone dane sugerują, że działanie peptydu p4 ogranicza się do kontroli liczebności bakterii zawiadujących agregacją innych, potencjalnie szkodliwych gatunków. Część spośród niewrażliwych na p4 gatunków bakterii jamy ustnej jest skutecznie eliminowana przez peptyd LL-37. Mieszanina peptydów antybakteryjnych, w składzie: p4, LL-37 oraz SLPI (ang. secretory leukocyte protease inhibitor) lepiej radzi sobie $\mathrm{w}$ hamowaniu wzrostu bakterii, w porównaniu do zastosowania w hodowli pojedynczych AMP. Obserwowany addytywny efekt działania peptydów pokazuje, że p4 może współdziałać z innymi AMP, zwiększając tym samym ochronę jamy ustnej przed niekontrolowanym wzrostem bakterii [37].

Oprócz funkcji antybakteryjnych, chemeryna może sprawować rolę czynnika chemotaktycznego, rekrutującego leukocyty do miejsc zapalenia. W płynach pobranych ze szczeliny dziąsłowej pacjentów z zapaleniem dziąseł lub paradontozą notuje się podobną ilość chemeryny. Jednakże, jej potencjał chemotaktyczny w przypadku obu stanów chorobowych może się znacząco różnić. Ma to związek z proteolityczną inaktywacją cząsteczki chemeryny do form nieaktywnych chemotaktycznie. Proteazy z rodziny gingi- pain, produkowane przez $P$. gingivalis są odpowiedzialne za unieczynnianie chemeryny. Natomiast chemeryna pochodząca od pacjentów z zapaleniem dziąseł skutecznie stymuluje komórki CMKLR1 ${ }^{+}$do migracji [37]. Przedstawione wyniki dowodzą, że chemeryna pełni funkcję czynnika antybakteryjnego oraz chemotaktycznego w początkowych etapach stanu zapalnego jamy ustnej.

Mikrobiom jelitowy jest najbardziej bogatym i złożonym siedliskiem mikroorganizmów w ludzkim organizmie. Ze względu na ciągłą ekspozycję czynników bakteryjnych oraz antygenów pokarmowych, błona śluzowa jelit jest wyposażona $\mathrm{w}$ szereg mechanizmów wspierających jej funkcje barierowe. Jednym $z$ nich jest produkcja AMP, które mają możliwość kształtowania składu mikrobiomu [39]. Do dnia dzisiejszego, niewiele jest wiadomo na temat ochronnej roli chemeryny w błonie śluzowej dolnych odcinków przewodu pokarmowego. $W$ nieswoistym zapaleniu jelit (IBD, ang. inflammatory bowel disease) obserwuje się lokalny wzrost ekspresji, sekrecji i aktywności chemeryny, skorelowany z nasileniem stanu zapalnego [40]. Podobnie, jak w przypadku wielu innych schorzeń jelit, również w IBD dochodzi do zaburzenia składu mikrobiomu [39]. U myszy brak chemeryny nie powoduje znaczących zmian w składzie bakterii jelitowych. Pewne różnice w kompozycji mikrobiomu obserwuje się natomiast u myszy z genetycznym deficytem receptora CMKLR1. Relatywnie niski poziom wyjściowej ekspresji chemeryny $w$ zdrowych jelitach sprawia, że w tych warunkach chemeryna zapewnia co najwyżej marginalny poziom ochrony przeciwbakteryjnej. Tymczasem, w czasie rozwoju procesu zapalnego potencjał przeciwbakteryjny chemeryny może zostać aktywowany [40]. Jak wiadomo, do miejsca gdzie toczy się stan zapalny są rekrutowane komórki układu odporności. Jednym ze skutków masowej migracji i aktywacji leukocytów jest pojawienie się dużej ilości reaktywnych form tlenu. Co ważne, pochodzący z chemeryny peptyd 4 zwiększa swoją aktywność w utleniającym środowisku. Dla przykładu, nadtlenek wodoru jest czynnikiem zwiększającym aktywność przeciwbakteryjną p4, dzięki zdolności do utleniania grup -SH, której rezultatem jest wytworzenie dimerów p4 [23]. Warto podkreślić, że w zdrowym jelicie ciśnienie parcjalne tlenu jest niskie, a im bliżej końca przewodu pokarmowego tym zawartość tlenu jeszcze bardziej spada. Panujące tam warunki redukujące są czynnikiem aktywującym niektóre AMP. Przykładem jest HBD-1, której potencjał antybakteryjny zależy w dużej mierze od zredukowania grup tiolowych w resztach cysteiny [30]. Na podstawie przytoczonych danych można stwierdzić, że chemeryna lub jej antybakteryjne pochodne nie są zaangażowane w konstytutywną ochronę jelita. Jednakże w szczególnych sytuacjach, np. w czasie stanu zapalnego istnieje możliwość aktywacji chemeryny, by ta mogła wspierać inne składniki odpowiedzi immunologicznej $\mathrm{w}$ walce $\mathrm{z}$ mikroorganizmami.

\section{PODSUMOWANIE}

Tkanka nabłonkowa wyposażona jest w wiele białek i peptydów o właściwościach przeciwdrobnoustrojowych i/ lub wpływających na działanie układu immunologicznego. Chemeryna jest niewielkim białkiem, którego zdolność do rekrutowania komórek odporności w miejsce zakażenia, 
wraz z aktywnością antybakteryjną dają możliwość wspierania funkcji ochronnych bariery nabłonkowej. Peptyd p4 odpowiada fragmentowi chemeryny $\mathrm{Val}^{66}-\mathrm{Pro}^{85}$ o największym potencjalne antybakteryjnym. Wykazuje właściwości bakteriobójcze względem istotnych z klinicznego punktu widzenia mikroorganizmów, takich jak metycylinooporne szczepy $S$. aureus, czy też bakterie tworzące patogenny biofilm jamy ustnej. Oprócz typowych uszkodzeń błony bakteryjnej, peptyd p4 posiada również unikalny mechanizm wzmocnienia swoich właściwości antybakteryjnych w środowisku utleniającym, co daje możliwość jeszcze skuteczniejszej walki z patogenami w miejscu, gdzie toczy się stan zapalny. Przedstawione w pracy przykłady zaangażowania chemeryny oraz peptydu p4 we wsparcie antybakteryjnej obrony skóry i jamy ustnej, otwierają nowe możliwości wykorzystania bioaktywnych fragmentów chemeryny w walce $\mathrm{z}$ bakteriami patogennymi, $\mathrm{w}$ tym szczepami lekoopornymi.

\section{PIŚMIENNICTWO}

1. Nagpal S1, Patel S, Jacobe H, DiSepio D, Ghosn C, Malhotra M, Teng M, Duvic M CR (1997) Tarazotene-induced Gene2, A novel retinoid-responsive gene. J Invest Dermatol 109: 91-95

2. Wittamer V, Franssen JD, Vulcano M, Mirjolet JF, Le Poul E, Migeotte I, Brézillon S, Tyldesley R, Blanpain C, Detheux M, Mantovani A, Sozzani S, Vassart G, Parmentier M, Communi D (2003) Specific recruitment of antigen-presenting cells by chemerin, a novel processed ligand from human inflammatory fluids. J Exp Med 198: 977-985

3. Helfer G, Wu Q (2018) Chemerin : a multifaceted adipokine involved in metabolic disorders. J Endocrinol 238: 79-94

4. Rourke JL, Dranse HJ, Sinal CJ (2013) Towards an integrative approach to understanding the role of chemerin in human health and disease. Obes Rev 14: 245-262

5. Ernst MC, Sinal CJ (2010) Chemerin: At the crossroads of inflammation and obesity. Trends Endocrinol Metab Elsevier Ltd 21: 660-667

6. Kulig P, Kantyka T, Zabel BA, Banas M, Chyra A, Stefanska A, Tu H AS, Handel TM, Kozik A, Potempa J, Butcher EC, Cichy J (2011) Regulation of chemerin chemoattractant and anti-bacterial activity by human cysteine cathepsins. J Immunol 187: 1403-1410

7. Kulig P, Zabel BA, Dubin G, Allen SJ, Ohyama T, Potempa J, Handel TM, Butcher EC, Cichy J (2007) Staphylococcus aureus-derived staphopain $\mathrm{B}$, a potent cysteine protease activator of plasma chemerin. J Immunol 178: 3713-3720

8. Zabel BA, Kwitniewski M, Banas M, Zabieglo K, Murzyn K, Cichy J (2014) Chemerin regulation and role in host defense. Am J Clin Exp Immunol 3: 1-19

9. Lei J, Sun LC, Huang S, Zhu C, Li P, He J, Mackey V, Coy DH, He QY (2019) The antimicrobial peptides and their potential clinical applications. Am J Transl Res 11: 3919-3931

10. Kennedy AJ, Davenport AP (2018) International union of basic and clinical pharmacology CIII: Chemerin receptors CMKLR1 (Chemerin1) and GPR1 (Chemerin2) nomenclature, pharmacology, and function. Pharmacol Rev 70: 174-196

11. De Henau O, Degroot GN, Imbault V, Robert V, De Poorter C, McHeik S, Galés C, Parmentier M, Springael JY (2016) Signaling properties of chemerin receptors CMKLR1, GPR1 and CCRL2. PLoS One 11: 1-20

12. Mattern A, Zellmann T, Beck-Sickinger AG (2014) Processing, signaling, and physiological function of chemerin. IUBMB Life 66: 19-26

13. Human Protein Atlas (2020) https://www.proteinatlas.org/ ENSG00000106538-RARRES2/ tissue (dostęp 23.03.2020)

14. Mariani F, Roncucci L (2014) Chemerin/chemR23 axis in inflammation onset and resolution. Inflamm Res 64: 85-95

15. Nakamura N, Naruse K, Kobayashi Y, Miyabe M, Saiki T, Enomoto A, Takahashi M, Matsubara T (2018) Chemerin promotes angiogenesis in vivo. Physiol Rep 6:1-13
16. Banas M, Zabieglo K, Kasetty G, Kapinska-Mrowiecka M, Borowczyk J, Drukala J, Murzyn K, Zabel BA, Butcher EC, Schroeder JM, Schmidtchen A, Cichy J (2013) Chemerin is an antimicrobial agent in human epidermis. Heimesaat MM (ed) PLoS One 8: e58709

17. Banas M, Zegar A, Kwitniewski M, Zabieglo K, Marczynska J, Kapinska-Mrowiecka M, LaJevic M, Zabel BA, Cichy J (2015) The Expression and Regulation of Chemerin in the Epidermis. Ryffel B (ed) PLoS One 10: $\mathrm{e} 0117830$

18. Goralski KB, McCarthy TC, Hanniman EA, Zabel BA, Butcher EC, Parlee SD, Muruganandan S, Sinal CJ (2007) Chemerin, a novel adipokine that regulates adipogenesis and adipocyte metabolism. J Biol Chem 282: $28175-28188$

19. Nakatsuji T, Gallo RL (2012) Antimicrobial peptides: Old molecules with new ideas. J Invest Dermatol 132: 887-895

20. Zhang L, Gallo RL (2016) Antimicrobial peptides. Curr Biol 26: R14R19

21. Mansour SC, Pena OM, Hancock REW (2014) Host defense peptides: Front-line immunomodulators. Trends Immunol 35: 443-450

22. McPhee JB, Hancock REW (2005) Function and therapeutic potential of host defense peptides. J Pept Sci 11: 677-687

23. Godlewska U, Bilska B, Zegar A, Brzoza P, Borek A, Murzyn K, Bochenska O, Morytko A, Kuleta P, Kozik A, Pyza E, Osyczka A, Zabel BA, Cichy J (2019) The antimicrobial activity of chemerin-derived peptide p4 requires oxidative conditions. J Biol Chem 294: 1267-1278

24. Kwiecien K, Zegar A, Jung J, Brzoza P, Kwitniewski M, Godlewska U, Grygier B, Kwiecinska P, Morytko A, Cichy J (2019) Architecture of antimicrobial skin defense. Cytokine Growth Factor Rev Elsevier 49: $70-84$

25. Qi RH, Chen Y, Guo ZL, Zhang F, Fang Z, Huang K, Yu HN, Wang YP (2019) Identification and characterization of two novel cathelicidins from the frog Odorrana livida. Zool Res 40: 94-101

26. Makowska M, Prahl A, Małuch I (2019) Charakterystyka peptydów przeciwdrobnoustrojowych oraz wpływ modyfikacji chemicznych na modulowanie ich aktywności biologicznej. Postepy Biochem 65: 278-288

27. Pfalzgraff A, Brandenburg K, Weindl G (2018) Antimicrobial peptides and their therapeutic potential for bacterial skin infections and wounds. Front Pharmacol 9: 1-23

28. Wang G (2011) Post-translational modifications of natural antimicrobial peptides and strategies for peptide engineering. Curr Biotechnol 1: 72-79

29. Wu Z, Hoover DM, Yang D, Boulègue C, Santamaria F, Oppenheim JJ, Lubkowski J, Lu W (2003) Engineering disulfide bridges to dissect antimicrobial and chemotactic activities of human $\beta$-defensin 3. Proc Natl Acad Sci U S A 100: 8880-8885

30. Schroeder BO, Wu Z, Nuding S, Groscurth S, Marcinowski M, Beisner J, Buchner J, Schaller M, Stange EF, Wehkamp J (2011) Reduction of disulphide bonds unmasks potent antimicrobial activity of human $\beta$ 2-defensin 1. Nature Nature Publishing Group 469: 419-423

31. Lorenzon EN, Piccoli JP, Santos-Filho NA, Cilli EM (2019) Dimerization of antimicrobial peptides: a promising strategy to enhance antimicrobial peptide activity. Protein Pept Lett 26: 98-107

32. Borek A, Ekiert R, Osyczka A (2016) Molekularne efekty mutacji mitochondrialnych w genie kodującym cytochrom. Postepy Biochem 1 $1-11$

33. Albanesi C, Scarponi C, Pallotta S, Daniele R, Bosisio D, Madonna S, Fortugno P, Gonzalvo-Feo S, Franssen JD, Parmentier M, De Pità O, Girolomoni G, Sozzani S (2009) Chemerin expression marks early psoriatic skin lesions and correlates with plasmacytoid dendritic cell recruitment. J Exp Med 206: 249-258

34. Chang HW, Yan D, Singh R, Liu J, Lu X, Ucmak D, Lee K, Afifi L, Fadrosh D, Leech J, Vasquez KS, Lowe MM, Rosenblum MD, Scharschmidt TC, Lynch S V, Liao W (2018) Alteration of the cutaneous microbiome in psoriasis and potential role in Th17 polarization. Microbiome 6: $1-27$

35. Grant M, Kilsgård O, Åkerman S, Klinge B, Demmer RT, Malmström J, Jönsson D (2019) The Human Salivary Antimicrobial Peptide Profile 
according to the oral microbiota in health, periodontitis and smoking. J Innate Immun 11: 432-443

36. Khurshid Z, Naseem M, Sheikh Z, Najeeb S, Shahab S, Zafar MS (2016) Oral antimicrobial peptides: Types and role in the oral cavity. Saudi Pharm J King Saud University 24: 515-524

37. Godlewska U, Brzoza P, Sroka A, Majewski P, Jentsch H, Eckert M, Eick S, Potempa J, Zabel BA, Cichy J (2017) Antimicrobial and attractant roles for chemerin in the oral cavity during inflammatory gum disease. Front Immunol 8: 353
38. Abranches J, Zeng L, Kajfasz JK, Palmer S, Chakraborty B, Wen Z, Richards VP, Brady LJ, Lemos JA (2019) Biology of oral streptococci. Gram-Positive Pathog 6: 426-434

39. Chang CS, Kao CY (2019) Current understanding of the gut microbiota shaping mechanisms. J Biomed Sci 26: 1-11

40. Dranse HJ, Zheng A, Comeau AM, Langille MGI, Zabel BA, Sinal CJ (2018) The impact of chemerin or chemokine-like receptor 1 loss on the mouse gut microbiome. PeerJ 2018: 1-29

\section{The role of chemerin and its antibacterial derivatives in maintaining epithelial barrier function}

\section{Urszula Godlewska ${ }^{\varpi}$, Aneta Zegar, Joanna Cichy}

Department of Immunology, Faculty of Biochemistry, Biophysics and Biotechnology, Jagiellonian University, Kraków

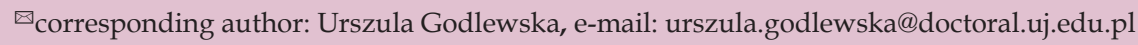

Key words: chemerin, antimicrobial peptides, peptide p4, antibacterial protection, skin, oral cavity

\section{SUMMARY}

The epithelial tissues have continuous contact with external environment, including pathogenic microorganisms. Endogenous antimicrobial proteins and peptides produced by epithelial cells play a key role in controlling microbial burden and composition, either directly, or by engaging immune cells. These include active derivatives of multifunctional protein chemerin, which is equipped with both antimicrobial and chemotactic function. Given an increasing number of infections caused by antibiotic-insensitive microorganisms, such as methicillinresistant S. aureus (MRSA), it is important to fully understand how these epithelia-associated microorganisms are controlled at barrier sites, including skin and oral cavity. Chemerin-derived synthetic peptide $4(\mathrm{p} 4)$ covering central Val ${ }^{66}-\mathrm{Pro}^{85} \mathrm{chemerin}$ sequence exhibits broad range of antimicrobial activity against skin- and oral cavity- associated bacteria, including MRSA strains, suggesting its therapeutic potential for bacteria-mediated barrier organs pathologies. In this article we present the overview of protective functions of chemerin and chemerin-derived peptides in the epithelial tissues. 